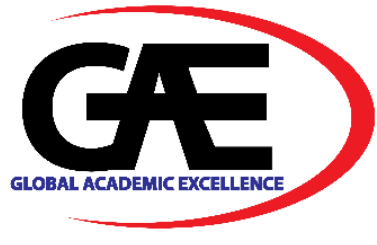

\title{
USER PERCEPTION USABILITY OF THE MALAYSIAN MOBILE TRIP PLANNER PLATFORM: A REVIEW STUDY
}

\author{
Hayder Naser Khraibet Al-Behadili ${ }^{*}$, Ku Ruhana Ku-Mahamud ${ }^{2}$ \\ 1 Computer Science Department, Shatt Al Arab University College, Iraq \\ Email: haider872004@gmail.com \\ 2 School of Computing, Universiti Utara Malaysia, Malaysia \\ Email: ruhana@uum.edu.my \\ Corresponding Author
}

\section{Article Info:}

\section{Article history:}

Received date: 23.03 .2020

Revised date: 10.09 .2020

Accepted date: 14.09.2020

Published date: 15.09.2020

\section{To cite this document:}

Al-Behadili, H. N. K., \& KuMahamud, K. R. (2020). User Perception Usability of The Malaysian Mobile Trip Planner Platform: A Review Study. Journal of Information System and Technology Management, 5 (18), 46-60.

DOI: $10.35631 / J I S T M .518005$.

\begin{abstract}
:
Tourism is important due to its benefits and role as a commercial activity that creates demand and growth in many industries. Tourism is vital not only in increasing economic activities but also in generating additional employment and revenue. Malaysia has increased its efforts in diversifying the economy and decreasing its dependence on exports by promoting increased tourism in the country. For this reason, the use of information technology in tourism has increased. Hence, mobile applications and applet tools play an important role among Internet users. This research reviews 24 standardised usability questionnaires in the literature for choosing the appropriate usability instrument. Then, this study investigated the usability measurement scales of the well-known mobile application, Malaysia Trip Planner, on the basis of Nielsen's usability principles. Therefore, this study could provide future research directions and recommendations on improving the attributes of such applications.
\end{abstract}

Keywords:

Information Technology; Trip Planner; Tourism; Mobile Application; Usability Testing instruments

\section{Introduction}

Numerous business reports have revealed that mobile technology has become an essential tool in improving tourism due to the natural increase in digital media consumption (e.g. mobile devices and tablets). Correspondingly, a Google study has indicated that many travellers use their smartphones during different stages of their travel for purposes of research, reservation, inspiration and experience. Additionally, the tools for searching travel information and Copyright $\odot$ GLOBAL ACADEMIC EXCELLENCE (M) SDN BHD - All rights reserved 


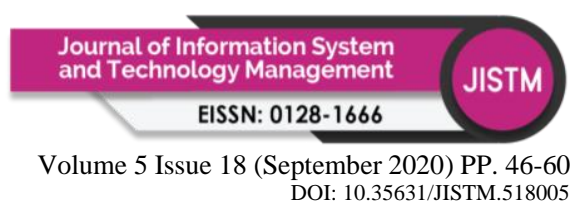

purchasing and booking options in the tourism sector have changed from the home desktop to mobile devices. Consequently, tourism has come to a tipping point whilst mobile application commerce has begun to represent a major share in booking reservations worldwide. Trip planner applications are a popular category in the mobile app market. In the coming years, such applications will be the main travel platform. Thus, additional functions with access to information, co-creative services and interactivity must be provided to users.

Usability is a quality factor that assesses the level of ease and enjoyment of consumers when utilising the features of software to achieve satisfaction, effectiveness and efficiency (Hussain et al., 2018, 2017; Mortada \& Hussain, 2019). In relation to the mobile tools of trip planner applications, previous studies have conducted investigations on increasing the business of individuals rather than the usability and adoption of such applications. In consideration of the limitations of previous studies, this study investigates the usability of tourism applications and provides recommendations on improving the quality features of software. The findings of this study are intended to help policy makers, designers and researchers for an improved understanding of the usability of such applications, provide a general rule in the design and promote the adoption of such software.

The remainder of this paper is structured as follows: A review of related literature is presented in Section 2. The evaluation method assessing the usability of the proposed calculator is discussed in Section 3. The experimental results of the proposed method are shown in Section 4. Lastly, recommendations on improving the usability and possible future research are provided in Section 5.

\section{Review on Usability Instruments}

The following factors have caused the emergence of many mobile applications in recent years: Firstly, laptops and desktop computers are not less portable than mobile devices. Secondly, the technology for logical bandwidth that is delivered to these mobile devices has grown efficiently, thus making mobile devices a helpful computing platform. Lastly, mobile users can customise their mobile platforms with mobile apps that meet their needs.

The number of applications downloaded via mobile applications is continuously increasing due to the millions of apps available on the iOS and Google Play platforms. Furthermore, the such tools are priced lower than those of personal computer software. Davis et al. (2003) developed a theoretical framework for this rapid adoption. This framework suggested that technology is adopted on the basis of its efficient usability and highly perceived usefulness, which is defined as understanding the ease of use in the model.

The improvement of mobile devices and their applications must be continued to understand their usability. Although many studies on the usability of smartphones have been conducted, majority of such investigations have focused on the operating system and hardware characteristics. Therefore, this study focused on the economy of single specialised apps (i.e. trip planner).

Several instruments have been used to measure the usability of smartphone applications, but finding a common instrument is the simplest way of consolidating the measurement. Famous instruments based on major digital libraries (Elsevier, Springer Link, ACM, Direct Science and IEEE Xplore) are presented as follows: 
Table 1: State-of-Art Usability Questionnaires

\begin{tabular}{|c|c|c|c|c|}
\hline No & Reference & $\begin{array}{c}\text { Standardized Usability } \\
\text { Questionnaires }\end{array}$ & User Type & $\begin{array}{l}\text { Items } \\
\text { scales }\end{array}$ \\
\hline 1 & (Davis, 1989) & $\begin{array}{l}\text { Technology Acceptance } \\
\text { Model questionnaire (TAM) }\end{array}$ & Computer software & 7 points \\
\hline 2 & (Chin et al., 1988) & $\begin{array}{l}\text { The Questionnaire for User } \\
\text { Interface Satisfaction (QUIS) }\end{array}$ & Computer software & 10 points \\
\hline 3 & $\begin{array}{ll}\text { (Kirakowski } \quad \& \\
\text { Cierlik, 1998) }\end{array}$ & $\begin{array}{l}\text { The Website Analysis and } \\
\text { Measurement } \\
\text { (AMI) }\end{array}$ & $\begin{array}{l}\text { Any kind of } \\
\text { websites }\end{array}$ & 5 points \\
\hline 4 & (Lewis, 1992) & $\begin{array}{l}\text { Post-Study System Usability } \\
\text { Questionnaire (PSSUQ) }\end{array}$ & Computer systems & 7 points \\
\hline 5 & $\begin{array}{l}\text { (Kirakowski \& } \\
\text { Corbett, 1993) }\end{array}$ & $\begin{array}{l}\text { The Software User } \\
\text { Measurement Inventory } \\
\text { (SUMI) }\end{array}$ & $\begin{array}{l}\text { Software } \\
\text { applications }\end{array}$ & 3 points \\
\hline 6 & (Brooke J., 1996) & $\begin{array}{l}\text { The System Usability Scale } \\
\text { (SUS) }\end{array}$ & Computer software & 5 points \\
\hline 7 & (Lewis, 1990) & $\begin{array}{l}\text { The After-Scenario } \\
\text { Questionnaire (ASQ) }\end{array}$ & Computer software & 7 points \\
\hline 8 & $\begin{array}{l}\text { (Lewis et al., } \\
\text { 2015) }\end{array}$ & Alternate Usability (AU) & Compute & 7 points \\
\hline 9 & (Lin et al., 1997) & $\begin{array}{l}\text { Purdue Usability Testing } \\
\text { Questionnaire (PUTQ) }\end{array}$ & $\begin{array}{l}\text { Information } \\
\text { systems }\end{array}$ & 7 points \\
\hline 10 & (Lund, 2001) & $\begin{array}{l}\text { The Usefulness, Satisfaction, } \\
\text { and Ease of use Questionnaire } \\
\text { (USEUQ) }\end{array}$ & Computer so & 7 points \\
\hline 11 & $\begin{array}{l}\text { (Chiew \& Salim, } \\
\text { 2003) }\end{array}$ & $\begin{array}{l}\text { Website Usability Evaluation } \\
\text { tool (WEBUSE) }\end{array}$ & $\begin{array}{l}\text { All types of } \\
\text { websites }\end{array}$ & 5 points \\
\hline 12 & (McGee, 2003) & $\begin{array}{l}\text { Usability Magnitude } \\
\text { Estimation (UME) }\end{array}$ & Computer software & $\begin{array}{l}\text { A rating } \\
\text { of } 1 \text { to } \\
100\end{array}$ \\
\hline 13 & $\begin{array}{l}\text { (Ryu \& Smith- } \\
\text { jackson, 2005) }\end{array}$ & $\begin{array}{l}\text { The Mobile Phone Usability } \\
\text { Questionnaire (MPUQ) }\end{array}$ & $\begin{array}{l}\text { All appli } \\
\text { mobile a }\end{array}$ & 7 points \\
\hline 14 & (Lewis, 1995) & $\begin{array}{l}\text { The Computer Software } \\
\text { Usability Questionnaire } \\
\text { (CSUQ) }\end{array}$ & Computer systems & ints \\
\hline 15 & $\begin{array}{l}\text { (Albert \& Dixon, } \\
\text { 2013) }\end{array}$ & Expectation Ratings (ER) & Computer software & 5 points \\
\hline 16 & $\begin{array}{l}\text { (Tedesco } \quad \& \\
\text { Tullis, 2006) }\end{array}$ & Single Ease Question (SEQ) & Computer software & 7 points \\
\hline 17 & $\begin{array}{l}\text { (Elling et al., } \\
2007 \text { ) }\end{array}$ & $\begin{array}{l}\text { Website } \quad \text { Evaluation } \\
\text { Questionnaire (WEQ) }\end{array}$ & $\begin{array}{l}\text { Governmental } \\
\text { websites }\end{array}$ & 5 points \\
\hline 18 & $\begin{array}{l}\text { (Sauro \& Dumas, } \\
\text { 2009) }\end{array}$ & $\begin{array}{l}\text { Subjective Mental Effort } \\
\text { Question (SMEQ) }\end{array}$ & Computer software & $\begin{array}{l}0 \text { to } 150 \\
\text { Graduated } \\
\text { scale }\end{array}$ \\
\hline 19 & $\begin{array}{l}\text { (Yang et al., } \\
\text { 2012) }\end{array}$ & $\begin{array}{l}\text { Design-oriented Evaluation } \\
\text { of Perceived usability (DEEP) }\end{array}$ & $\begin{array}{l}\text { Information- web } \\
\text { systems }\end{array}$ & 5 points \\
\hline
\end{tabular}




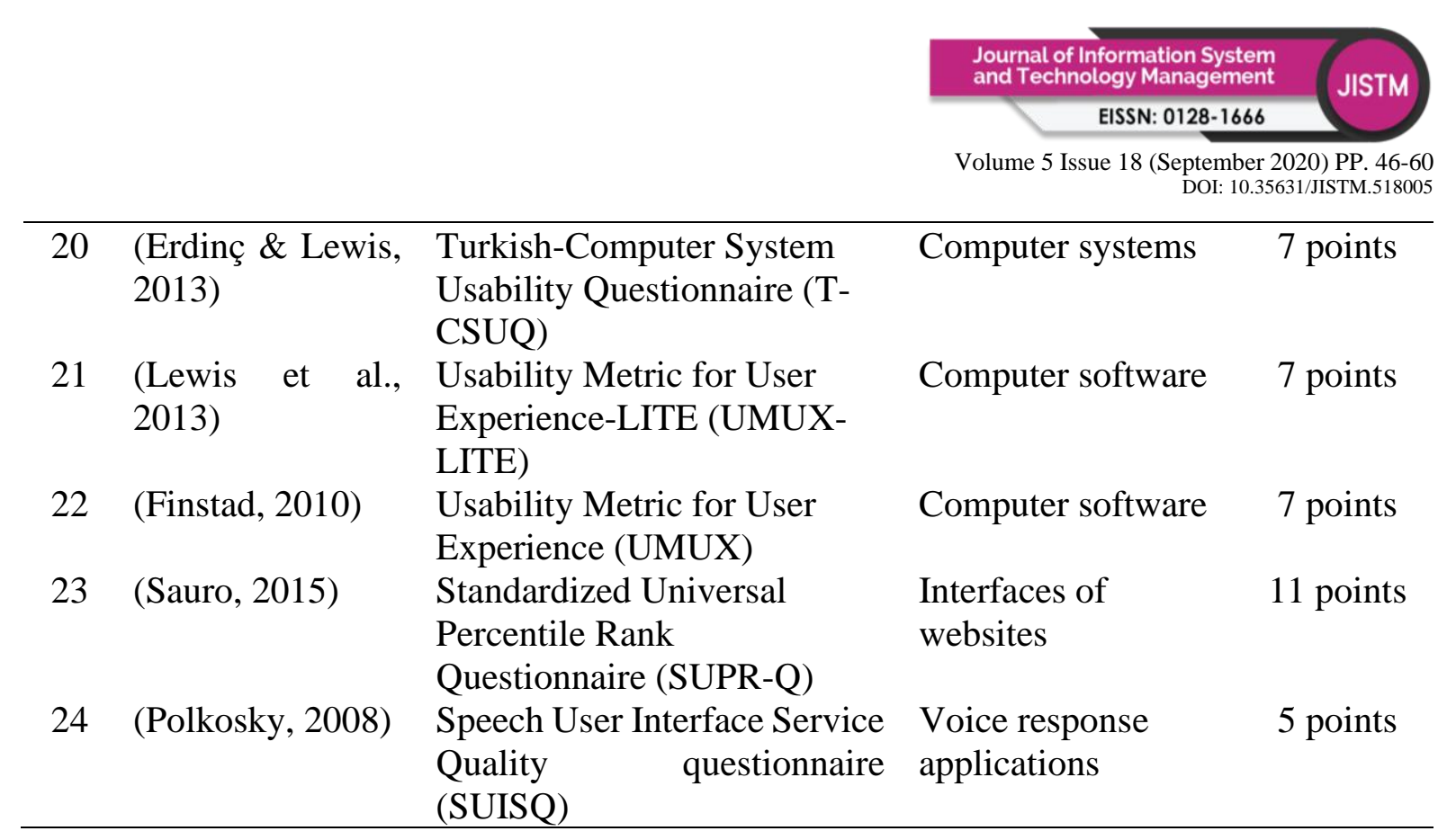

On the basis of the selected characteristics, different methods have been proposed for the classification of questionnaires, as shown in Table 1. Yang, Linder and Bolchini (2012) classified the questionnaires into three types based on interface or system usage and named them universal, website and mobile usability questionnaires. Universal questionnaires are used in any type of electronic product. The following are examples of different applications that use universal questionnaires: TAM tests the usability of virtual learning systems and augmented reality applications (Milis, Wessa, Poelmans, Doom, \& Bloemen, 2008; Chandrasekera, 2014); QUIS is used in educational software and vending machines (Ak1ll1, 2005; Naeini \& Mostowfi, 2015); PSSUQ is utilised in research information systems; SUMI is applied to systems of product data management (Erik \& Cisa, 1998); SUS is used in serious games (De Asmundis, 2014); ASQ is utilised in office application systems and nursing information (Lewis, 1990; Liaskos \& Mantas, 2006); PUTQ is applied to recommender systems (Zins et al., 2004); USEUQ is utilised in robotic telepresence systems; UME is used in travel applications (Sauro \& Dumas, 2009); CSUQ is found in virtual learning systems (Milis et al., 2008) and in information system (AL-Behadili et al., 2013); ER and SEQ are used in intranet site applications (Tedesco \& Tullis, 2006); SMEQ can be found in travel application systems (Sauro \& Dumas, 2009); T-CSUQ is applied to systems of web-based course management (Erdinç \& Lewis, 2013); and UMUX-LITE and UMUX are used in e-learning applications (Borsci et al., 2015). Standardised usability questionnaires are used in websites (e.g. AMI, WEBUSE, WEQ, SUPR-Q and DEEP). The mobile phone usability questionnaire (MPUQ) is a type of mobile application questionnaire. The widely used Nielsen's principles as shown in Figure 1 were considered in testing the usability of Malaysia's mobile-based trip planner (Nielsen, 2012; Ramrecha et al., 2018). These principles are:

i. Learnability factor, this quality factor focusses in learnability level of end-users that utilize the Malaysian mobile trip planner for first time.

ii. Efficiency factor, this factor comes after the end-users have learned the mobile application. It is checking the execution time that end-users need to perform tasks on Malaysian mobile trip planner.

iii. Memorability factor, this factor checks how easy that user can remember the Malaysian mobile trip planner after a period of not using it.

iv. The error factor, this factor checks the quality throughout the system and how many errors present in the mobile application as well as how easy to recover from them. 
v. The final factor is satisfaction, this factor related to how easy end-users can utilize the Malaysian mobile trip planner application. Figure 1 below shows the main factors of Nielsen's usability principles.

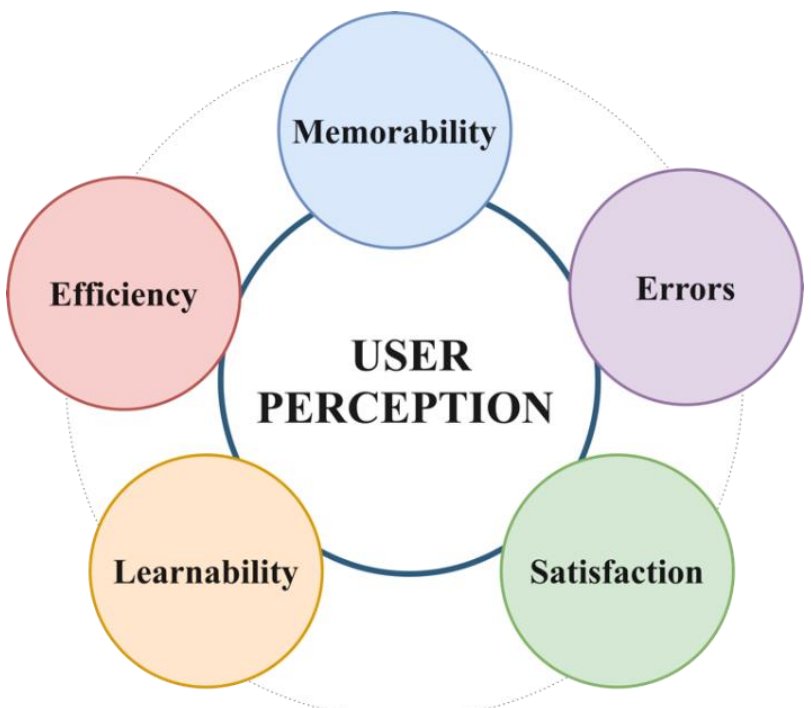

Figure 1: Nielsen's Usability Principles

Therefore, the MPUQ instrument was modified on the basis of these principles. Some items, which were irrelevant to this research, were removed (e.g. Is it easy to check missed calls?). The next section explains the research methodology of this study.

\section{Method}

This study was conducted at the University Utara Malaysia with 20 participants consisting of international postgraduate students of information technology. The participants were IT specialist and selected through random sampling in accordance with Faulkner (1998) standard number of users lies between 5 and 20 to solve usability problems (Faulkner, 2003; Gilbert et al., 2007). Our work focused on testing the usability of the trip planner platform and its main factors that contribute to the quality of mobile application usability.

The instrument used in our work is a survey questionnaire based on a revised version of the MPUQ. The questionnaire consists of two parts. The first part includes the general demographic information of the students. This basic information consists of gender and educational background. The second part is a 17-item questionnaire on the five factors of learnability, efficiency, memorability, errors and satisfaction, which are considered the most possible factors in the usability of mobile application. The students must choose their software level of usability for each factor using a five-point Likert scale ranging from strongly agree, agree, neutral, disagree and strongly disagree.

The validity and reliability of the instrument are important to ensure that the entire testing process meets all the research objectives. George and Mallery (2003) argued that items could have high reliability if they achieve a score of at least 0.8 (Cronbach's alpha) in the reliability statistics (analysis). Our research questionnaire (MPUQ) was used to indicate the usability of mobile phone applications. In all these academic works, MPUQ has demonstrated reliability 


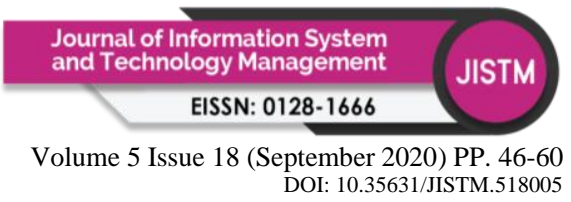

and validity. For example, Ryu \& Smith-Jackson (2005) conducted an investigation on mobile usability, and its Cronbach's alpha was 0.96, which demonstrates high internal reliability.

The Malaysian Trip Planner application can provide a single view of all your trips. The four main interfaces of this application are Explore, My Itinerary, What's on and Nearby Attractions, as shown in Figure 2. The Explore interface allows the user to explore the best places tourists can visit in Malaysia. The second interface allows tourists to plan their route or journey. The third interface shows Malaysian events in a given period of time. The last interface presents the nearby attractions and proposes activities within the vicinity.
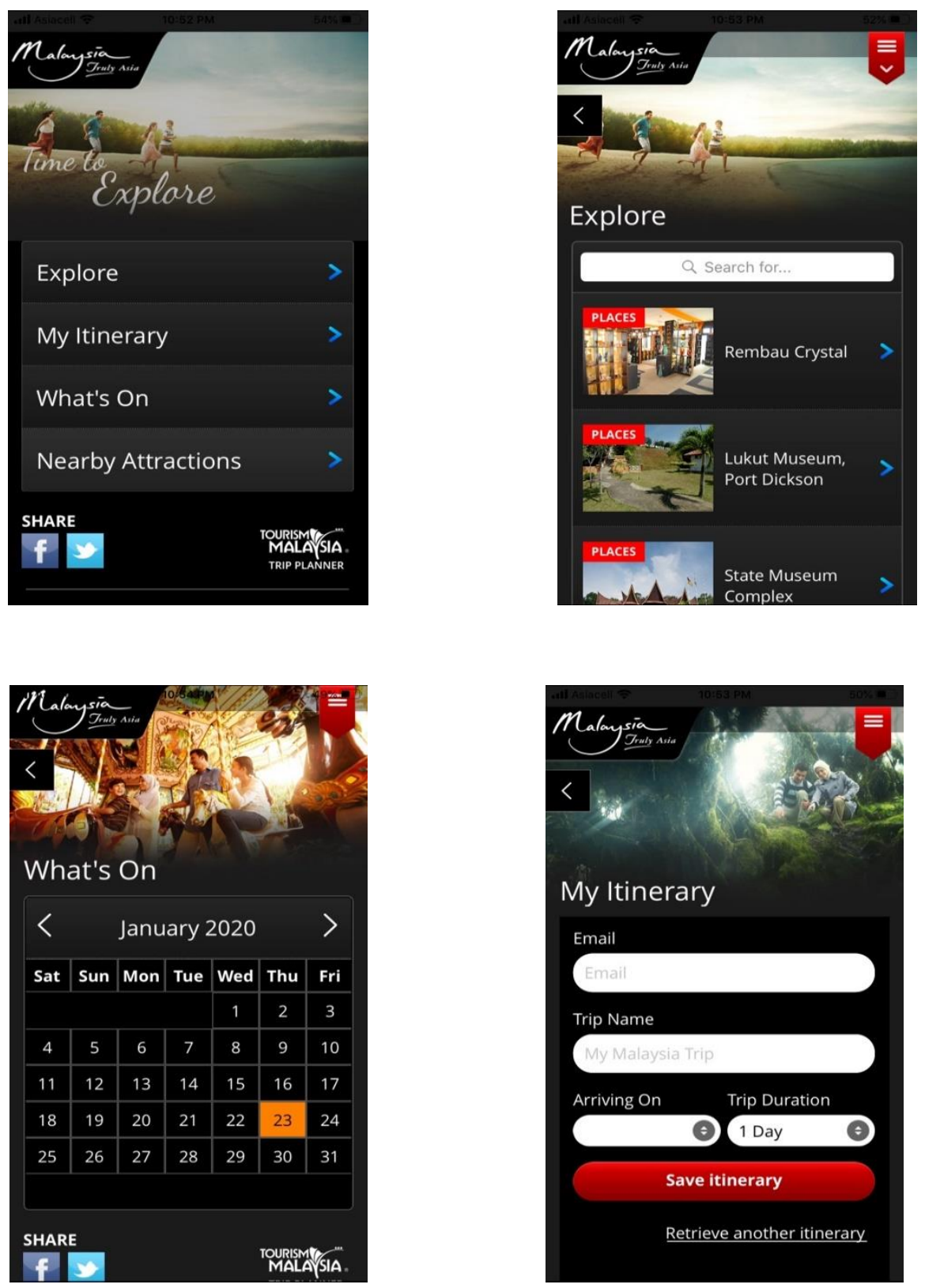

Figure 2: Key Screenshots of the Malaysia Trip Planner 
To test the usability of the platform, Nielsen's concept was considered due to its popularity. The modified instrument based on the five main factors (learnability, efficiency, memorability, errors and satisfaction) of Nielsen's principles are shown in Table 2. The following factors aimed to evaluate the ease of use of interfaces:

- Learnability is related to the level to which end-users feel.

- Efficiency entails how fast end-users can perform tasks.

- Memorability refers to how easy a system can be remembered by the user.

- Errors show the minimum number of errors in any application.

- Satisfaction involves how pleased a user is on the design of an application.

Table 2: The Modified Instrument Based on Nielsen's Principles

\begin{tabular}{lll}
\hline No & Attribute & \\
\hline 1 & & The application operates easy. \\
2 & \multirow{2}{*}{ Learnability } & Easy to read characters on the screen. \\
3 & & Types of effort to interacting this application. \\
4 & & Easy control, operate and regulate this application. \\
5 & & Speed of the information display and response time. \\
6 & Efficiency & Does the application occasionally stopped? \\
7 & & Data sufficiently consistent in this application. \\
8 & & Data index well in this application. \\
9 & Memorability & Data items are short and clear. \\
10 & & The items highlight on the screen are helpful? \\
11 & \multirow{2}{*}{ Errors } & Typos mistakes are easy to edit. \\
12 & & This application is easy to operate with one hand. \\
13 & & Is this application attractive and pleasing? \\
14 & & The application has attractive colour. \\
15 & Satisfaction & The application has attractive brightness. \\
16 & & Overall, comfortable and confident with this application. \\
17 & & Overall, satisfaction with the application. \\
\hline
\end{tabular}

The validity and reliability of the questionnaire are important to ensure that the entire experimental concept is established. Furthermore, the results obtained must meet all the research objectives. According to the literature, the instrument can have high reliability if they achieve a score of at least 0.8 (Cronbach's alpha) in the reliability statistics (analysis). Our revised questionnaire version MPUQ was checked, and the result of Cronbach's alpha for this study was 0.84 , which demonstrates high internal reliability.

\section{Results}

The first section of the questionnaire includes the general demographic information of the participants. This basic information consists of gender and postgraduate degree. The total number of respondents in the study is 20 . The demographic profile of the respondents is shown in Table 3. 
Table 3: Demographic Profile of Respondents

\begin{tabular}{|c|c|c|}
\hline Gender of Participants & Type of participants & Total \\
\hline \multirow{2}{*}{ Male } & Master & 4 \\
\hline & $\mathrm{PhD}$ & 8 \\
\hline \multirow{2}{*}{ Female } & Master & 4 \\
\hline & $\mathrm{PhD}$ & 4 \\
\hline Tota & & 20 \\
\hline
\end{tabular}

Table 4 presents the final statistical information results from the selected participants about the system usability. This part of the questionnaire aims to check the major factors affecting application usability. These factors are learnability, efficiency, memorability, errors and satisfaction, which are further classified in the following subsections to show the descriptive statistics of each factor. The subsections show the average usability level for each item.

Table 4: The Statistical Information About the System Usability Instrument

\begin{tabular}{|c|c|c|c|c|c|c|}
\hline \multirow[b]{2}{*}{ Questions } & \multicolumn{3}{|c|}{ Strongl } & \multirow[b]{2}{*}{$\underset{1}{\text { Netutra }}$} & \multirow[b]{2}{*}{$\begin{array}{l}\text { Agre } \\
\text { e }\end{array}$} & \multirow[b]{2}{*}{$\begin{array}{l}\text { Strongl } \\
\text { y Agree }\end{array}$} \\
\hline & $\begin{array}{c}\text { Tota } \\
\mathbf{l}\end{array}$ & $\begin{array}{c}\mathbf{y} \\
\text { Disagre } \\
\mathbf{e}\end{array}$ & $\begin{array}{c}\text { Disagre } \\
\mathbf{e}\end{array}$ & & & \\
\hline The application operates easy. & 20 & $0 \%$ & $5 \%$ & $15 \%$ & $65 \%$ & $15 \%$ \\
\hline $\begin{array}{l}\text { Easy to read characters on the } \\
\text { screen. }\end{array}$ & 20 & $0 \%$ & $0 \%$ & $20 \%$ & $55 \%$ & $25 \%$ \\
\hline $\begin{array}{l}\text { Types of effort to interacting } \\
\text { this application. }\end{array}$ & 20 & $0 \%$ & $5 \%$ & $50 \%$ & $40 \%$ & $5 \%$ \\
\hline $\begin{array}{l}\text { Easy control, operate and } \\
\text { regulate this application. }\end{array}$ & 20 & $0 \%$ & $5 \%$ & $15 \%$ & $60 \%$ & $20 \%$ \\
\hline $\begin{array}{l}\text { Speed of the information } \\
\text { display and response time. }\end{array}$ & 20 & $0 \%$ & $10 \%$ & $40 \%$ & $50 \%$ & $0 \%$ \\
\hline $\begin{array}{l}\text { Does the application } \\
\text { occasionally stop? }\end{array}$ & 20 & $0 \%$ & $5 \%$ & $35 \%$ & $55 \%$ & $5 \%$ \\
\hline $\begin{array}{l}\text { Data sufficiently consistent in } \\
\text { this application. }\end{array}$ & 20 & $0 \%$ & $5 \%$ & $45 \%$ & $50 \%$ & $0 \%$ \\
\hline $\begin{array}{l}\text { Data index well in this } \\
\text { application. }\end{array}$ & 20 & $0 \%$ & $5 \%$ & $45 \%$ & $45 \%$ & $5 \%$ \\
\hline Data items are short and clear. & 20 & $0 \%$ & $0 \%$ & $50 \%$ & $50 \%$ & $0 \%$ \\
\hline $\begin{array}{l}\text { The items highlight on the } \\
\text { screen are helpful? }\end{array}$ & 20 & $0 \%$ & $10 \%$ & $30 \%$ & $55 \%$ & $5 \%$ \\
\hline $\begin{array}{l}\text { Typos mistakes are easy to } \\
\text { edit. }\end{array}$ & 20 & $0 \%$ & $25 \%$ & $25 \%$ & $50 \%$ & $0 \%$ \\
\hline $\begin{array}{l}\text { This application is easy to } \\
\text { operate with one hand. }\end{array}$ & 20 & $0 \%$ & $0 \%$ & $60 \%$ & $35 \%$ & $5 \%$ \\
\hline $\begin{array}{l}\text { Is this application attractive } \\
\text { and pleasing? }\end{array}$ & 20 & $0 \%$ & $0 \%$ & $40 \%$ & $60 \%$ & $0 \%$ \\
\hline The application has attractive & 20 & $0 \%$ & $0 \%$ & $10 \%$ & $90 \%$ & $0 \%$ \\
\hline
\end{tabular}




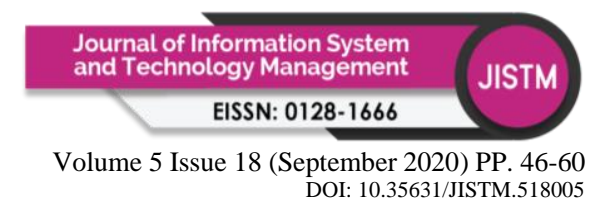

The application has attractive brightness.

20

$0 \% \quad 0 \% \quad 40 \% \quad 55 \% \quad 5 \%$

Overall, comfortable and

confident with this

20

$0 \% \quad 0 \% \quad 35 \% \quad 45 \% \quad 20 \%$

application.

Overall, satisfaction with the

application.

20

$0 \%$

$0 \%$

$15 \% \quad 65 \%$

$20 \%$

In the learnability factor, question 1 asks about how easy it is for the users to learn how to operate the application; the results in Table 5 show that the respondents agree to the ease of learning the application (Mean $=3.9$ and $\mathrm{Sd}=0.79)$. Question 2 asks about the characters on the screen; the results reveal that the respondents are satisfied (Mean $=4.05$ and $\mathrm{Sd}=1.00$ ). In question 3, participants are asked about their feeling when interacting with the application; the results show that the respondents feel neutral (Mean $=3.45$ and $\mathrm{Sd}=0.93$ ). In question 4 , the respondents agree (Mean $=3.95$ and $\mathrm{Sd}=0.93$ ) on the ease of operation and control of the application.

Table 5: Mean of the Learnability Factor

\begin{tabular}{lc}
\hline \multicolumn{1}{c}{ Measured Item } & Mean Score \\
The application operates easy. & 3.9 \\
Easy to read characters on the screen. & 4.05 \\
Types of effort to interacting this application. & 3.45 \\
Easy control, operate and regulate this application. & 3.95 \\
\hline
\end{tabular}

The efficiency scale includes three items (5, 6 and 7) in the MPUQ questionnaire, as shown in Table 6. Question 5 asks about the response time and information display; the answers were neutral (Mean $=3.4$ and $\mathrm{Sd}=0.34$ ). Table 6 lists the results of question 6 . The findings also show that one of the participants could speak English better than the others to a certain degree. Table 6 presents the results of question 7, including the instances where the application stopped unexpectedly. The answers of the respondents to this question are neutral (Mean $=3.6$ and $\mathrm{Sd}$ $=0.4$ ). The results of question 7 demonstrate that the data display is sufficiently consistent. The dominantly neutral results are shown in Table $6($ Mean $=3.45$ and $\mathrm{Sd}=0.3)$.

Table 6: Mean of the Efficiency Factor

\begin{tabular}{lc}
\multicolumn{1}{c}{ Measured Item } & Mean Score \\
Speed of the information display and response time. & 3.4 \\
Does the application occasionally stopped? & 3.6 \\
Data sufficiently consistent in this application. & 3.45 \\
\hline
\end{tabular}

The memorability factor includes three items (8, 9 and 10). The answers of respondents to question 8 show the index data of the application. The results are listed in Table 7, and most of the participants agree with this question (Mean $=3.5$ and $\mathrm{Sd}=0.75$ ). Question 9 asks whether the data items are kept short; majority of the respondents agree (Mean $=3.5$ and $\mathrm{Sd}=0.45)$. The answers to question 10 are shown in Table 7. Question 10 is related to whether the highlighting on the screen is helpful; majority of the respondents agree. Hence, the contributors agree $($ Mean $=3.55$ and $\mathrm{Sd}=0.64)$. 
Table 7: Mean of the Memorability Factor

\begin{tabular}{lc}
\hline Measured Item & Mean Score \\
Data index well in this application. & 3.5 \\
Data items are short and clear. & 3.5 \\
The items highlight on the screen are helpful? & 3.55 \\
\hline
\end{tabular}

The error factor of MPUQ has two items (11 and 12). In question 11, the participants are asked about the ease of correcting mistakes; the responses are neutral, as shown in Table 8 (Mean = 3.25 and $\mathrm{Sd}=0.2$ ). Item 12 asks about how the application operates; the responses show that the respondents agree $($ Mean $=3.45$ and $\mathrm{Sd}=1.13)$.

Table 8: Mean of the Errors Factor

\begin{tabular}{lc} 
Measured Item & Mean Score \\
Typos mistakes are easy to edit. & 3.25 \\
This application is easy to operate with one hand. & 3.45 \\
\hline
\end{tabular}

The last factor is satisfaction, which includes five items $(13,14,15,16$ and 17). The results of question 13 show how attractive and pleasing the application is. The results show that majority of the respondents agree with the item $(\mathrm{Mean}=3.6$ and $\mathrm{Sd}=0.75)$. Question 14 involves the attractiveness of the colour of the application. The results show that majority of the participants agree to this question (Mean $=3.9$ and $\mathrm{Sd}=0.85$ ). In question 15 , the participants are asked about the brightness of the application to which the respondents agree (Mean $=3.65$ and $\mathrm{Sd}=$ 1.02). Question 16 determines the comfort and confidence of the user whilst operating the application. The responses show that the participants agree (Mean $=3.85$ and $\mathrm{Sd}=0.5$ ). Question 17 determines the overall satisfaction of the user with the application. The results show that majority of respondents strongly agree $(\mathrm{Mean}=4.05$ and $\mathrm{Sd}=0.25)$.

Table 9: Mean of the Satisfaction Factor

\begin{tabular}{lc}
\hline Measured Item & Mean Score \\
Is this application attractive and pleasing? & 3.6 \\
The application has attractive colour. & 3.9 \\
The application has attractive brightness. & 3.65 \\
Overall, comfortable and confident with this application. & 3.85 \\
Overall, satisfaction with the application. & 4.05 \\
\hline
\end{tabular}

The mean score for all the attributes of the usability quality factors is less than 4, which shows an overall result lying at the midpoint of the frequency distribution and a positive result for the usability of the proposed application. Amongst the factors, learnability and satisfaction obtain the highest mean scores because most of the participants successfully learned how to use the application with ease and were satisfied with the application. However, errors obtain the least score due to some errors that occurred during the usage of the application. Overall, the system obtains a usability of 3.65 in the proposed tool. Figure 3 illustrates the comparison of the different quality attributes. 


\section{Comparison of Usability Attributes}

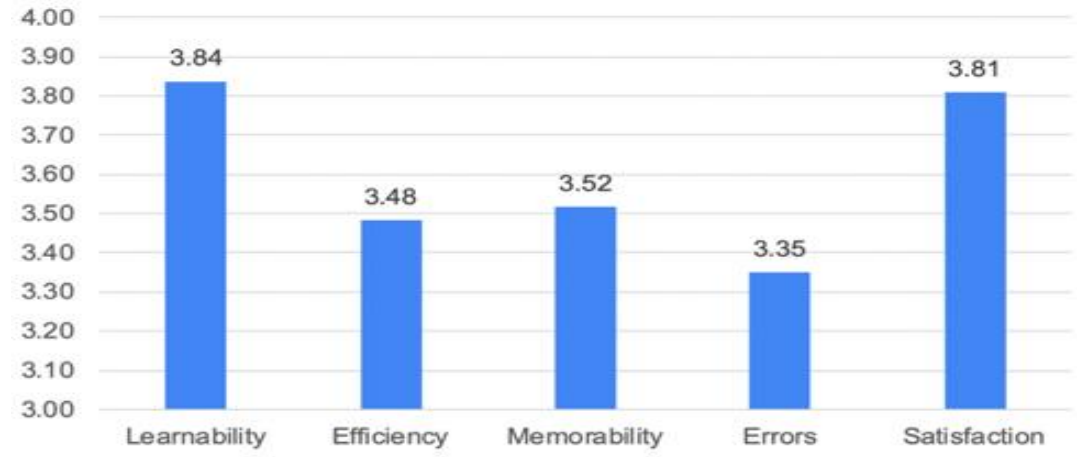

Figure 3: Comparison of the Usability Attributes

Therefore, regarding to T-test result of the usability factors among gender types. Table 10 display that students gender has no significant effect on all the three usability factors (learnability, efficiency and memorability). In addition, by using the t-test to indicates that there is a significant effect on two usability factors (errors and satisfaction), P-Value (20) $=0.048$ and 0.037 , respectively. It can be seen for the means that both males and females demonstrated a different level of system usability in errors and satisfaction factors, respectively.

Table 10: T-Test Result of Nielsen's Usability Factors with Respect to User's Type of Study

\begin{tabular}{cccccc}
\hline Factors & Gender & N & Mean & $\begin{array}{c}\text { Std. } \\
\text { Deviation }\end{array}$ & P-Value \\
& Female & 8 & 3.813 & 0.260 & 0.418 \\
Learnability & Male & 12 & 3.854 & 0.322 & \\
& Female & 8 & 3.292 & 0.144 & 0.052 \\
Eefficiency & Male & 12 & 3.611 & 0.173 & \\
& Female & 8 & 3.458 & 0.072 & 0.334 \\
\multirow{2}{*}{ Errors } & Male & 12 & 3.556 & 0.048 & \\
\multirow{2}{*}{ Satisfaction } & Female & 8 & 3.063 & 0.265 & 0.048 \\
& Male & 12 & 3.542 & 0.059 & \\
& Female & 8 & 3.650 & 0.105 & 0.037 \\
\hline
\end{tabular}

On the other hand, the results in Table 11 shows that there are no significant differences between user's type of study and the usability factors. The experimental result shows that there is no significant difference between $\mathrm{PhD}$ and Master students on all usability factors. It can be seen for the means that both $\mathrm{PhD}$ and Master demonstrated a rapprochement level in all usability factors. 
Volume 5 Issue 18 (September 2020) PP. 46-60 DOI: $10.35631 /$ JISTM.518005

Table 11: T-Test Result of Nielsen's Usability Factors with Respect to User's Type of Study

\begin{tabular}{cccccc}
\hline Factors & Gender & $\mathbf{N}$ & Mean & $\begin{array}{c}\text { Std. } \\
\text { Deviation }\end{array}$ & P-Value \\
& Master & 8 & 3.750 & 0.354 & 0.233 \\
Learnability & $\mathrm{PhD}$ & 12 & 3.896 & 0.239 & \\
Efficiency & Master & 8 & 3.292 & 0.072 & 0.050 \\
& $\mathrm{PhD}$ & 12 & 3.611 & 0.210 & \\
Memorability & Master & 8 & 3.542 & 0.191 & 0.427 \\
& $\mathrm{PhD}$ & 12 & 3.500 & 0.144 & \\
Errors & Master & 8 & 3.375 & 0.000 & 0.445 \\
\multirow{2}{*}{ Satisfaction } & $\mathrm{PhD}$ & 12 & 3.333 & 0.236 & \\
& Master & 8 & 3.800 & 0.190 & 0.457 \\
\hline
\end{tabular}

\section{Conclusions}

This research aimed to review standardised usability questionnaires for choosing the appropriate usability instrument. In this review, we find that the items of MPUQ questionnaires according to Nielsen's concept, suitable for mobile trip planner platform. The results based on items of MPUQ indicated that the application offered an enriching mobile experience to most of the participants in the study. Majority of the users perceived that the trip planner application satisfied their needs in terms of the five usability qualities evaluated in this study. In addition, this study indicates that male users make fewer errors than female users, while using the system. Therefore, the satisfaction evaluation of male is more than female users. However, some issues on findability demand attention and improvement in subsequent application updates. Lastly, with the development and emergence of new technologies, the design of usability instruments is required to deal with different types of mobile applications (e.g. health care, business and education).

\section{References}

Ak1ll, G. K. (2005). User Satisfaction Evaluation of an Educational Website. The Turkish Online Journal of Educational Technology - TOJET.

AL-Behadili, H. N. K., Mousa, A. H., \& Shahbani, M. (2013). Intelligent Iraqi Health System ( Iihs ) Using Online Analytical Process ( Olap ) Model. The 4th International Conference on Computing and Informatics, ICOCI 2013, 072, 201-207.

Albert, W. S., \& Dixon, E. (2013). Is this what you expected? The use of expectation measures in usability testing. Usability Professionals Association, 12thAnnual Conference,. https://doi.org/10.5152/ced.2011.01

Borsci, S., Federici, S., Bacci, S., Gnaldi, M., \& Bartolucci, F. (2015). Assessing User Satisfaction in the Era of User Experience: Comparison of the SUS, UMUX, and UMUX-LITE as a Function of Product Experience. International Journal of HumanComputer Interaction. https://doi.org/10.1080/10447318.2015.1064648

Brooke J. (1996). SUS-A quick and dirty usability scale. Usability Evaluation in Industry.

Chiew, T. K., \& Salim, S. S. (2003). Webuse: Website usability evaluation tool. Malaysian Journal of Computer Science.

Chin, J. P., Diehl, V. A., \& Norman, K. L. (1988). Development of an instrument measuring user satisfaction of the human-computer interface. Conference on Human Factors in Computing Systems - Proceedings. https://doi.org/10.1145/57167.57203 


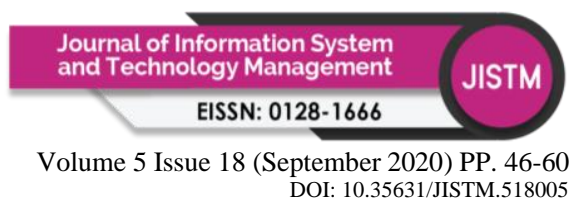

Davis, F. D. (1989). Perceived usefulness, perceived ease of use, and user acceptance of information technology. MIS Quarterly: Management Information Systems. https://doi.org/10.2307/249008

De Asmundis, R. (2014). An evaluation model to measure impact and usability of a serious game. University of Bari Aldo Moro.

Elling, S., Lentz, L., \& De Jong, M. (2007). Website evaluation questionnaire: Development of a research-based tool for evaluating informational websites. Lecture Notes in Computer Science (Including Subseries Lecture Notes in Artificial Intelligence and Lecture Notes in Bioinformatics). https://doi.org/10.1007/978-3-540-74444-3_25

Erdinç, O., \& Lewis, J. R. (2013). Psychometric Evaluation of the T-CSUQ: The Turkish Version of the Computer System Usability Questionnaire. International Journal of Human-Computer Interaction. https://doi.org/10.1080/10447318.2012.711702

Erik, D., \& Cisa, P. W. M. V. V. (1998). Questionnaire based usability testing. Conference Proceedings European Software Quality Week, Brussels.

Faulkner. (2003). Beyond the five-user assumption: Benefits of increased sample sizes in usability testing. Behavior Research Methods, Instruments, \& Computers, 35(3), 379383. https://doi.org/10.1109/DCABES.2011.32

Finstad, K. (2010). The usability metric for user experience. Interacting with Computers. https://doi.org/10.1016/j.intcom.2010.04.004

George, D., \& Mallery, P. (2003). SPSS for Windows Step by Step: Answers to Selected Exercises. In A Simple Guide and Reference. https://doi.org/9780335262588

Gilbert, J., Andrea, W., \& Cheryl, S. (2007). Clustering for usability participant selection. Journal of Usability Studies, 3(1), 40-52.

Hussain, A., Mkpojiogu, E. O. C., Almazini, H., \& Almazini, H. (2017). Assessing the usability of Shazam mobile app. The 2nd International Conference on Applied Science and Technology 2017 (ICAST'17), 1891(October). https://doi.org/10.1063/1.5005390

Hussain, A., Mkpojiogu, E. O. C., Musa, J., \& Mortada, S. (2018). Mobile experience evaluation of an e-reader app. Journal of Telecommunication, Electronic and Computer Engineering, 10(1-10), 11-15.

Kirakowski, J., \& Cierlik, B. (1998). Measuring the usability of web sites. Proceedings of the Human Factors and Ergonomics Society. https://doi.org/10.1177/154193129804200405

Kirakowski, J., \& Corbett, M. (1993). SUMI: the Software Usability Measurement Inventory. British Journal of Educational Technology. https://doi.org/10.1111/j.14678535.1993.tb00076.x

Lewis, J. R. (1990). Psychometric evaluation of an after-scenario questionnaire for computer usability studies. ACM SIGCHI Bulletin. https://doi.org/10.1145/122672.122692

Lewis, J. R. (1992). Psychometric evaluation of the post-study system usability questionnaire: the PSSUQ. Proceedings of the Human Factors Society. https://doi.org/10.1177/154193129203601617

Lewis, J. R. (1995). IBM Computer Usability Satisfaction Questionnaires: Psychometric Evaluation and Instructions for Use. International Journal of Human-Computer Interaction. https://doi.org/10.1080/10447319509526110

Lewis, J. R., Utesch, B. S., \& Maher, D. E. (2013). UMUX-LITE - When there's no time for the SUS. Conference on Human Factors in Computing Systems - Proceedings. https://doi.org/10.1145/2470654.2481287 


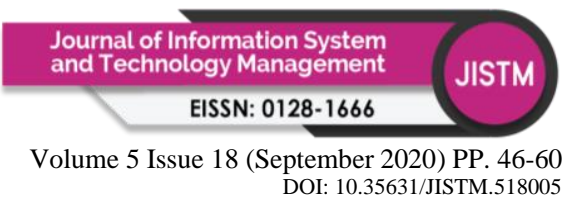

Lewis, J. R., Utesch, B. S., \& Maher, D. E. (2015). Measuring Perceived Usability: The SUS, UMUX-LITE, and AltUsability. International Journal of Human-Computer Interaction. https://doi.org/10.1080/10447318.2015.1064654

Liaskos, J., \& Mantas, J. (2006). Measuring the user acceptance of a web-based nursing documentation system. Methods of Information in Medicine. https://doi.org/10.1055/s0038-1634047

Lin, H. X., Choong, Y. Y., \& Salvendy, G. (1997). A proposed index of usability: A method for comparing the relative usability of different software systems. Behaviour and Information Technology. https://doi.org/10.1080/014492997119833

Lund, A. M. (2001). Measuring usability with the USE questionnaire. Usability Interface. https://doi.org/10.1177/1078087402250360

McGee, M. (2003). Usability Magnitude Estimation. Proceedings of the Human Factors and Ergonomics Society Annual Meeting. https://doi.org/10.1177/154193120304700406

Milis, K., Wessa, P., Poelmans, S., Doom, C., \& Bloemen, E. (2008). The impact of gender on the acceptance of virtual learning environments. Proceedings of the International Conference of Education, Research and Innovation, International Association of Technology, Education and Development.

Mortada, S., \& Hussain, A. (2019). The evaluation of EMGS mobile application: Users experience. International Journal of Innovative Technology and Exploring Engineering, 8(5s), 246-250.

Naeini, H. S., \& Mostowfi, S. (2015). Using QUIS as a Measurement Tool for User Satisfaction Evaluation (Case Study: Vending Machine). International Journal of Information Science. https://doi.org/10.5923/j.ijis.20150501.03

Nielsen, J. (2012). Usability 101: Introduction to Usability. https://www.nngroup.com/articles/usability-101-introduction-to-usability/

Polkosky, M. D. (2008). Machines as mediators: The challenge of technology for interpersonal communication theory and research. In Mediated Interpersonal Communication. https://doi.org/10.4324/9780203926864

Ramrecha, V., Bekaroo, G., Santokhee, A., \& Juddoo, S. (2018). Exploring the application and usability of NFC for promoting self-learning on energy consumption of household electronic appliances. IEEE 4th International Conference on Soft Computing and Machine Intelligence, ISCMI 2017. https://doi.org/10.1109/ISCMI.2017.8279617

Ryu, Y. S., \& Smith-jackson, T. L. (2005). Development of usability questionnaire items for mobile products and content validity. Proceedings of Human Computer Interaction International, 22-27.

Sauro, J. (2015). SUPR-Q: a comprehensive measure of the quality of the website user experience. Journal of Usability Studies.

Sauro, J., \& Dumas, J. S. (2009). Comparison of three one-question, post-task usability questionnaires. Conference on Human Factors in Computing Systems - Proceedings. https://doi.org/10.1145/1518701.1518946

T. Chandrasekera. (2014). Using Augmented Reality Prototypes in Design Education. Design and Technology Education: An International Journal.

Tedesco, D. P., \& Tullis, T. S. (2006). A Comparison of Methods for Eliciting Post-Task Subjective Ratings in Usability Testing. Upa 2006.

Yang, T., Linder, J., \& Bolchini, D. (2012). DEEP: Design-oriented evaluation of perceived usability. International Journal of Human-Computer Interaction. https://doi.org/10.1080/10447318.2011.586320 
Volume 5 Issue 18 (September 2020) PP. 46-60 DOI: 10.35631/JISTM.518005

Zins, A. H., Bauernfeind, U., Del Missier, F., Mitsche, N., Ricci, F., Rumetshofer, H., \& Schaumlechner, E. (2004). Prototype Testing for a Destination Recommender System: Steps, Procedures and Implications. In Information and Communication Technologies in Tourism 2004. https://doi.org/10.1007/978-3-7091-0594-8_24 